\title{
Alys Russell: a bibliography
}

Alys Pearsal1 Smith Russe11 (1867-1951), Bertrand Russell's first wife, was an early "libber" who not only worked politically for women's rights but a1so sought to improve the immediate social conditions of poor women. She was involved deeply in movements for temperance, better factory conditions, and higher education. No one, however, has paid her any attention since her death, perhaps because the material relating to her has never been brought together. are more numerous than anyone had supposed, and are quite delightful is sure to be incomplete. Some of her writings ar grand-niece, Miss Barbara Halpern, has told us she is planning to write a biography of Alys. Ms. Kearn' ' bibliography will be most helpful in any such projects, Alys. Ms. Kearns bibliography will besches 


\section{Works by}

1888. A WOMEN'S COLLEGE IN THE UNITED STATES. Nineteenth Century, 23: June, 918-26.

1894. A REPLY FROM THE DAUGHTERS. Nineteenth Century, 35: March, $443-$ 50 .

1896. SOCIAL DEMOCRACY AND THE WOMAN QUESTION IN GERMANY. Appendix in German Social Democracy by Bertrand Russell. London: Longmans, Green. Pp. 173-95.

1896. THE WOMAN MOVEMENT IN GERMANY. Nineteenth Century, 40: July, 97-104.

1903. FOUR DAYS IN A FACTORY. Contemporary Review, 84: July, 52-61. Reprinted in Living Age, 238: 15 Aug. 1903, 433-40, and Eclectic Magazine, 141: Oct. 1903, 464- .

1903. L'EDUCATION DES FEMMES. Bibliothèque du Congrès International de Philosophie, Vol. II. Paris: Líbrarie Armand Colin, 1903. Pp. 309-17. Delivered in 1900 .

1906. THE GHENT SCHOOL FOR MOTHERS. Nineteenth Century and After, 60 Dec., 970-5. Reprinted in Living Age, 252: 2 Feb. 1907, 292-6.

1907. SOME LESSONS IN CO-EDUCATION FROM THE UNITED STATES. Oxford and Cambridge Review, no. 1: June, 84-94.

1910. THE ST. PANCRAS MOTHERS' AND BABIES' WELCOME. The queen, 127 (3288): 1 Jan., 23. Reprinted in Edwardian Promenade (London: Edward Hulton, 1958).

1928. FIRST SCHOOL FOR MOTHERS COMES OF AGE. Child Health Bulletin, 4: Nov., $178-81$

1948. HOW TO ENJOY LIFE AT EIGHTY. The Listener, 40(1033): 11 Nov., $722-3$.

1949. WHEN THE FABIANS WERE YOUNG. The Listener, 41(1044): $27 \mathrm{Jan}$, $133-4$

1949. Preface to Recollections of Logan Pearsall Smith, by Robert Gathorne-Hardy. London: Constable; New York: Macmillan, 1950.

1969. Letters in The Autobiography of Bertrand Russell, Vol. III: 194467. London: George Allen and Unwin; New York: Simon and Schuster.

\section{Works about}

1905. MRS. BERTRAND RUSSELL. By I.M. Hami11. Sunday Magazine (Lon.) 34: $539-40$.

1947. Finch, Edith. Carey Thomas of Bryn Mawr. New York and London: Harper and Brothers.

1948. Webb, Beatrice. Our Partnership. Ed. Barbara Drake and Margaret I. Cole. London and New York: Longmans, Green.

1949. A Religious Rebel: the letters of "H.W.S." (Mrs. Pearsall Smith). Ed. Logan Pearsa11 Smith, with a preface and memoir by R. GathorneHardy. London: Nisbet, 1949. Contains letters to Alys from her

1950. A Portrait of Logan Pearsall smith drawn from his letters. Ed. John Russell. London: Dropmore Press.

1951. OBITUARY. The New York Times, 22 Jan., 17.

OBITUARY. Time, 57(5): 29 Jan., 36.

OBITUARY. The Times, 23 Jan., 6; 29 Jan., 6.

1959. Parker, Robert Allerton. The Transatlantic Smiths. New York: Random House. English ed, as A Fomily of Friends (London: Museum Press, 1960).
1967-9. Russe11, Bertrand. The Autobiography of Bertrand Russell. 3 vols.

1969. Whitman, Walt. The Correspondence. Ed. Edwin Haviland Miller. Vol. IV 1886-1889. Vo1. V 1890-1892. New York: New York University Press. Contains letters from Whitman to Alys.

\section{Papers}

1) Miss Barbara Halpern, London, England, seems to have the bulk of Alys's papers; they are not publicly available. Miss Halpern intends writing a biography of Alys.

2) The library of the London School of Economics has a scrapbook kept by Alys of the Russe1ls' visit to Germany in late 1895; photocopy in the Russell Archives.

3) The Bertrand Russell Archives has Russell's letters to Alys (including some 50 acquired in Archives II), and other materials.

4) Bryn Mawr College.

5) The Manuscript Division, Library of Congress, has papers of Logan Pearsall Smith, including some letters to Alys; some copies are in the Russell Archives. Also at LC are Alys's letters to Walt Whitman, presented by Charles E. Fineberg.

6) The Princeton University Library also has papers of Logan, which include a photograph of Alys.

7) The library of Kent State University a1so has some of Logan's papers, including some very early correspondence with Alys.

8) The Bernard Berenson Archives, in Italy, contain many letters from Alys to Bernard and Alys's sister Mary. Copies are in the Russell

Eastwood, Australia

Marion Kearns 